\title{
CONFECÇÃO E AVALIAÇÃO DE INCUBADORA E MEIOS DE CULTURA DE BAIXOS CUSTOS COMO MATERIAIS DIDÁTICOS PARA PRÁTICAS DE MICROBIOLOGIA NO ENSINO MÉDIO
}

\author{
Lucy Ono ${ }^{1}$, Júlia Maria Klein Lopes², Suzana Marcovicz Follador², Rafael José \\ Marques $^{3}$, Dara Aline Tolentino Dia ${ }^{2}$ \\ 1 Docente do Departamento de Patologia Básica, colaboradora do Programa de Mestrado \\ Profissional em Ensino de Biologia em Rede Nacional - ProfBio, Universidade Federal do \\ Paraná, Brasil. \\ ${ }^{2}$ Graduanda do Curso de Farmácia, Programa de Voluntariado Acadêmico, Universidade \\ Federal do Paraná, Brasil. \\ 3 Docente do Colégio Estadual Neide Bertasso Beraldo Ensino Fundamental e Médio, \\ Secretaria de Estado da Educação do Paraná, Paiçandu - PR, Brasil \\ Email para correspondência: lono@ufpr.br
}

\begin{abstract}
Resumo
A motivação para aprender tem implicações diretas no envolvimento dos estudantes com o processo de ensino-aprendizagem, podendo ser impulsionada, na área de Biologia, pela realização de atividades práticas investigativas. Este trabalho propõe auxiliar na estruturação de laboratórios de Microbiologia na Educação Básica, e foi desenvolvido no Laboratório de Microbiologia Yasuyoshi Hayashi/UFPR, por meio de colaboração entre discentes do Curso de Farmácia/UFPR e do Programa de Mestrado Profissional em Ensino de Biologia em Rede Nacional (PROFBIO), no período de abril de 2018 a março de 2020. Foram confeccionados meios de cultura caseiros (ANC1 e ANC2, tendo em comum extrato de levedura e ágar Kanten na composição) e foi construída uma incubadora de isopor com materiais de menor custo e facilmente disponíveis no comércio local. Os meios apresentaram resultados iguais ou ligeiramente inferiores de quantificação de $E$. coli e $S$. aureus em incubadora de isopor quando comparados ao ágar PCA. A avaliação do meio ANC1 e da incubadora de isopor para isolamento de bactérias do ambiente mostrou crescimento de diferentes bactérias, indicando bom potencial de utilização desses em aulas práticas investigativas de Microbiologia no Ensino Médio.
\end{abstract}

Palavras-chave: ensino, microbiologia, materiais alternativos.

\begin{abstract}
The motivation to learn has direct implications on students getting involved with their teaching-learning process, and could be boosted in the Biology field by performing investigative laboratory activities. This work proposes to assist the structuring of Microbiology laboratories in Basic Education, and was carried out at the Yasuyoshi Hayashi Microbiology Laboratory/UFPR, through collaboration
\end{abstract}




\begin{abstract}
between students from the Pharmacy Course/UFPR and the Professional Master's Program in Biology Teaching in National Network (PROFBIO), from April 2018 to March 2020. Homemade culture media (ANC1 and ANC2, with yeast extract and Kanten agar in the composition) were produced and a polystirene foam incubator was built using low-costs materials easily available in local market. The homemade media showed equal or slightly lower results for the quantification of $E$. coli and $S$. aureus in the polystirene foam incubator when compared to the PCA agar. The evaluation of the ANC1 medium and the polystirene foam incubator for isolating bacteria from the environment showed growth of different bacteria, indicating good potential for using them in investigative Microbiology classes in High School.
\end{abstract}

Keywords: teaching, microbiology, alternative materials.

\title{
1 Introdução
}

A Microbiologia pode ser definida como a área da Ciência dedicada ao estudo dos microrganismos (vírus, microalgas, protozoários, fungos, bactérias e arqueias), que apresentam dimensões da ordem micrométrica e nanométrica (MADIGAN et al., 2014).

O estudo dos microrganismos merece atenção especial segundo Gitti (2014) quando são apresentados em aulas práticas, pois sendo este um mundo microscópico para a compreensão dos alunos, a realização de práticas faz com que possam compreender, construir e assimilar o que são os microrganismos e como funcionam. O conceito de microrganismo costuma ser ligado a algo negativo, já culturalmente trazido pelos alunos, como afirma Cassanti et al. (2008), sendo evidenciado pela observação de que a maioria dos estudantes se lembra dos microrganismos associados às doenças e, devido a isso, não correlacionam os microrganismos às suas ações benéficas ao homem, animais e ambiente. É papel do educador mudar a visão do educando, afirma Cândido et al. (2015), mostrando que a maioria dos microrganismos é benéfica à saúde humana, ou ainda, desempenham funções ecológicas fundamentais para a manutenção da vida na terra (OVIGLI; SILVA, 2009).

E ainda, as Diretrizes Curriculares Nacionais da Educação Básica (DCN), bem como a Base Nacional Comum Curricular (BNCC), na área de Biologia, trazem um conteúdo amplo e adaptável em que podem ser reconhecidos elementos que referenciam à biologia dos microrganismos, ressaltando a importância da experimentação como estratégia para a abordagem de temas nesta área (BRASIL, 2013; BRASIL, 2020).

A realização de atividades práticas investigativas na área da Microbiologia com os estudantes da Educação Básica é uma ferramenta importante na 
consolidação dos conceitos estudados, pois os exercícios de reflexão, formulação de hipóteses, elaboração de protocolos experimentais, execução de experimentos, descrição de resultados, interpretações e conclusões, ajudam o aluno a construir um modo de pensar crítico e científico, e portanto, contribuem significativamente para o seu desenvolvimento e autonomia (BARBOSA; BARBOSA, 2010). As aulas práticas proporcionam ao discente visualizar os processos biológicos e observar resultados inesperados cujas interpretações desafiam sua imaginação e raciocínio, buscando de forma ativa 0 conhecimento, como afirma Krasilchik (2008).

Diversos são os reagentes e equipamentos necessários para a experimentação em um laboratório de Microbiologia, e, mais especificamente, para a realização de práticas que envolvam o isolamento e identificação preliminar de bactérias e, os custos relativamente altos para a montagem dessa infraestrutura para as aulas, dificultam a realização de experiências de Microbiologia com os alunos do Ensino Médio da rede pública de ensino.

Comunidades e grupos de biólogos amadores ao redor do mundo criaram um movimento denominado Do It Yourself Biology (DIYbio, https://diybio.org/), fundado em 2008 em Boston, com a filosofia de tornar a biologia acessível e motivadora a todos aqueles que tiverem interesse em praticá-la. O DIYbio defende a importância da alfabetização científica para a sociedade moderna, compartilhando projetos como o de criação de dispositivos caseiros de emissão de bioluminescência e utilizando materiais facilmente acessíveis para o público em geral (DELGADO, 2013; LANDRAIN et al., 2013).

Em um estudo realizado com 416 estudantes do ensino médio de escolas públicas do Estado de São Paulo, Scheley, Silva e Campos (2014) avaliaram fatores que poderiam ser associados à motivação para aprender na área de Biologia. Neste estudo, dentre as atividades que deveriam ocorrer mais frequentemente durante as aulas para que eles se sentissem mais motivados em aprender, os alunos indicaram em maior percentual, na categoria de atividades, a subcategoria "Prática", seguida de "Experiências" e a "Extra Escola/Sala de Aula", que costumam ser atividades que acontecem menos frequentemente ou não acontecem nas escolas.

Este trabalho propôs, portanto, como um primeiro passo para auxiliar na estruturação de laboratórios de Microbiologia na Educação Básica, a confecção 
e a avaliação da eficiência de uma incubadora de isopor e de meios de cultura similares aos convencionais, de menor custo e construídos com materiais facilmente disponíveis no comércio local.

\section{Metodologia}

Esse artigo descreve um relato de experiência realizada no Laboratório de Microbiologia Yasuyoshi Hayashi do Departamento de Patologia Básica da UFPR com o auxílio de três estudantes do curso de Farmácia do Programa de Voluntariado Acadêmico da UFPR e, em colaboração com um docente do Ensino Médio da rede estadual paranaense pública do município de Paiçandu, no período em que esteve matriculado no Programa de Mestrado Profissional em Ensino de Biologia em Rede Nacional - PROFBIO. A pesquisa foi realizada no período de abril de 2018 a março de 2020, sendo vinculada ao projeto intitulado "Estruturando laboratório de baixo custo para facilitar o processo de ensino-aprendizagem de Microbiologia no Ensino Médio" da Universidade Federal do Paraná.

\subsection{Construção de incubadora bacteriológica de isopor de baixo custo}

Foi adquirido um kit chocadeira (Digitle, modelo D1), regulado para $37,5^{\circ} \mathrm{C}$, sendo composto por 1 termostato digital, 1 resistência 150W (110V), 1 fonte $12 \mathrm{~V} 2,5 \mathrm{~A}, 1$ cooler $12 \mathrm{~V} 80 \times 80 \times 25 \mathrm{~mm}, 1$ cabo de energia de 1,5m, 4 roldanas de porcelana, 1 conector sindal, 1 madeira MDF de fixação $(20 \times 30 \mathrm{~cm})$ e parafusos de fixação.

Este kit foi parafusado à tampa de uma caixa de isopor de capacidade 40L (com área da tampa tendo $37 \times 60 \mathrm{~cm}$ ) com pistola de cola quente e foram feitos 4 furos na tampa de isopor com o auxílio de uma ponta de chave Philips 1/4x5", um em cada canto da tampa (à distância de $5 \mathrm{~cm}$ de cada aresta) recobertos com tela de nylon que foi colada na tampa com cola quente para diminuir a condensação de água no interior da caixa.

\subsection{Avaliação qualitativa de ágar a granel e ágar Kanten para escolha do} produto a ser utilizado na formulação dos meios de cultura caseiros

O ágar a granel (Gracilaria sp.) e o ágar Kanten (Gelidium sp.) foram suspensos em água mineral na concentração de $10 \mathrm{~g} / \mathrm{L}$, concentração indicada 
por ZAREI et al. (2016), e seu pH ajustado para 7,0, utilizando tubos de centrifugação cônicos de $50 \mathrm{~mL}$ e submetidos à autoclavação $\left(121^{\circ} \mathrm{C}, 20 \mathrm{~min}\right)$.

Após o resfriamento e solidificação do ágar em temperatura ambiente, os géis produzidos foram retirados dos tubos e sua textura foi avaliada com uma espátula de alumínio, determinando qual produto permitiria a solidificação do meio em condições de textura mais próximas de meios de cultura bacterianos comerciais. As concentrações adicionais de $20 \mathrm{~g} / \mathrm{L}$ e $40 \mathrm{~g} / \mathrm{L}$ também foram avaliadas para o ágar a granel, por ter apresentado fraca gelificação a $10 \mathrm{~g} / \mathrm{L}$.

\subsection{Formulação de meios de cultura bacterianos caseiros}

Foram avaliadas duas formulações similares ao Ágar PCA comercial para contagem de placas, com componentes que foram adquiridos em casas de produtos naturais, supermercado e loja de suplementos alimentares.

As formulações foram ajustadas para pH 7,0 a 7,5, com solução de $\mathrm{NaOH}$ $1 \mathrm{~N}$ ou $\mathrm{HCl} 1 \mathrm{~N}$, utilizando papel indicador universal de $\mathrm{pH}$ escala 0-14.

a) Formulação 1 para Ágar Nutriente caseiro (adaptado de ZAREl et al., 2016):

Ágar Kanten $10,0 \mathrm{~g}$

Extrato de levedura caseiro $1,0 \mathrm{~L}$

- Modo de preparo do extrato de levedura caseiro: o fermento biológico fresco (250g, Fleischmann) foi suspenso em uma jarra de vidro com água mineral em quantidade suficiente para 1 litro, colocado em frascos de vidro cobertos por papel alumínio dobrado 4 vezes e preso por elástico de látex dentro de uma panela de pressão de 7 litros de capacidade contendo 1,5 litros de água (para a formação de vapor durante aquecimento e a esterilização por meio de calor úmido) e foi submetido à temperatura aproximada de $120^{\circ} \mathrm{C}$ após saída de vapor contínuo pela panela sob aquecimento em fogão elétrico de 1 boca, por um período de 30 minutos (panela de pressão chiando médio por 15 minutos) e resfriamento gradual em temperatura ambiente (para evitar a quebra do recipiente de vidro). Após o resfriamento inicial para alcançar a temperatura ambiente, o frasco foi resfriado a $\sim 8^{\circ} \mathrm{C}$ por 72 horas para a sedimentação e posterior coleta do sobrenadante. $O$ sobrenadante foi coletado cuidadosamente, evitando-se tocar o sedimento, com o auxílio de pipeta de 
$10 \mathrm{~mL}$ acoplada a uma pera de sucção e filtrado por filtro de papel de coagem de café, e o líquido filtrado, após ter volume medido e completado com quantidade suficiente para $1 \mathrm{~L} \mathrm{com} \mathrm{água} \mathrm{mineral.}$

- Modo de preparo do ágar nutriente 1: ao extrato de levedura caseiro foi adicionado o ágar Kanten, que após suspensão em frasco de vidro de capacidade $500 \mathrm{~mL}$, teve seu $\mathrm{pH}$ ajustado para 7,0 a 7,5 (foram necessários cerca de $1,5 \mathrm{~mL}$ de solução de $\mathrm{NaOH} 1 \mathrm{M}$ para cada frasco de $500 \mathrm{~mL}$ de meio para conseguir alcançar o pH neutro) e foi submetido à esterilização em panela de pressão de capacidade 7 litros contendo 1,5 litros de água (é importante que o frasco não boie sobre a água que está no fundo da panela de pressão), por um período de 30 minutos após saída de vapor contínuo pela panela (panela de pressão chiando médio por 30 minutos). A confirmação de alcance da temperatura de esterilização foi realizada por meio de colagem de um segmento de fita adesiva para autoclave no frasco de vidro, que é termossensível, tornando-se listrado ao final do processo. Após resfriamento da panela sob água corrente, os frascos contendo o meio foram retirados da panela e o meio ainda líquido distribuído em placas de Petri de poliestireno esterilizadas (diâmetro $90 \mathrm{~mm}, 25 \mathrm{~mL} /$ placa) em fluxo laminar.

b) Formulação 2 para Ágar Nutriente caseiro (adaptado de GARVEY, 2018):

Peptona de soja caseira $2,5 \mathrm{~mL}$

Sal grosso sem iodo $1,2 \mathrm{~g}$

Ágar Kanten $10,0 \mathrm{~g}$

Extrato de levedura caseiro. qsp $1,0 \mathrm{~L}$

- O extrato de levedura caseiro foi preparado como já descrito para a formulação 1;

- Modo de preparo da peptona de soja caseira: a proteína isolada de soja em pó isoflavona $(100 \mathrm{~g})$ foi suspensa em água mineral $(500 \mathrm{~mL})$ em uma panela e aquecida a $100^{\circ} \mathrm{C}$ por $5 \mathrm{~min}$ para a inativação de inibidores de protease do produto. A suspensão foi esfriada até $\sim 45^{\circ} \mathrm{C}$, com observação por meio de termômetro químico, quando foi adicionado o suco da polpa de 1 abacaxi maduro (Ananas comosus) variedade Hawaí (200mL), que serviu de fonte da protease bromelina, também aquecido a $45^{\circ} \mathrm{C}$. Para o preparo do suco de abacaxi, foram utilizados $\sim 360 \mathrm{~g}$ da polpa do abacaxi liquidificados em 
$300 \mathrm{~mL}$ de água mineral, que após filtração por coador do tipo peneira, resultou em volume de $200 \mathrm{~mL}$ se suco. Com o auxílio de uma panela em banho maria, a suspensão foi levada ao fogão elétrico ocasionalmente para mantê-la aquecida próxima de $45^{\circ} \mathrm{C}$ por um período de 20 minutos. Após esse tempo, a suspensão foi fervida por pelo menos 5 minutos para inativar a bromelina. Foi realizada fervura adicional para concentrar a peptona de soja produzida até 0 volume final de $500 \mathrm{~mL}$, sob agitação constante. $\mathrm{O} \mathrm{pH}$ final foi ajustado para 7,0 a 7,5;

- Modo de preparo do ágar nutriente 2: ao extrato de levedura caseiro foram adicionados a peptona de soja caseira, sal grosso e o ágar Kanten, que após suspensão, foi submetido a esterilização em panela de pressão aquecida em fogão elétrico de 1 boca por um período de 30min após saída de vapor contínuo pela panela. A confirmação de alcance da temperatura de esterilização foi realizada por meio de fita adesiva para autoclave. A distribuição em placas de Petri foi realizada como descrito para a formulação 1.

\subsection{Avaliação dos meios caseiros em relação aos meios padrões e avaliação da estufa padrão em relação à estufa de isopor}

Foram preparadas suspensões com 24 horas de crescimento em ágar PCA das bactérias Escherichia coli (ATCC 25922) e Staphylococcus aureus (ATCC 25923) em solução de $\mathrm{NaCl}$ 0,85\% esterilizada, equivalentes à turbidez do tubo

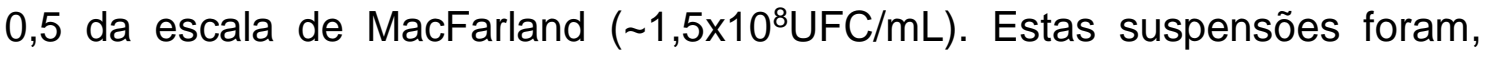
posteriormente, diluídas até cerca de $1,5 \times 10^{3} \mathrm{UFC} / \mathrm{mL}$. As suspensões $(50 \mu \mathrm{L})$ foram distribuídas homogeneamente na superfície dos meios (controle PCA, teste ANC1 e teste ANC2, com 5 repetições para cada meio) em placas de Petri de $90 \mathrm{~mm}$ com auxílio de alça de Drigalski e foram incubadas na posição invertida a $37^{\circ} \mathrm{C}$ em estufa padrão ou em estufa de isopor por 48 horas. Os resultados de contagem de colônias desenvolvidas (e as respectivas concentrações de unidades formadoras de colônias) foram expressas como número médio \pm desvio padrão e analisados pelo teste $t$ de Student com $P<0,05$ (BOLTON, 1990).

O meio de cultura caseiro ANC1 foi utilizado posteriormente para semeadura de amostras ambientais. Previamente à semeadura, as placas foram incubadas por 24 horas para verificar a esterilidade e ao mesmo tempo 
secar a superfície e retirar a água de condensação das tampas. Após a semeadura, as placas foram incubadas em incubadora caseira de isopor a $37^{\circ} \mathrm{C}$ por 48 horas, período após o qual foram produzidos esfregaços em lâminas de vidro de suspensões das colônias bacterianas obtidas que foram fixados e corados pela técnica de coloração de Gram com posterior observação em objetiva de imersão (100x) com magnificação total de 1.000x (CHICOSKI et al., 2019).

As culturas bacterianas foram produzidas seguindo 0 uso de equipamentos de proteção individual e as normas de biossegurança de trabalho em laboratórios de Microbiologia (SANGIONE et al., 2013).

As culturas bacterianas obtidas neste trabalho foram inativadas por meio de autoclavação $\left(121^{\circ} \mathrm{C}, 30\right.$ minutos) antes de serem descartadas, mas como alternativa, poderia ser seguido o protocolo de Kamiyama (1970) utilizando panela de pressão de capacidade 7 litros, contendo 1,5 litros de água, aquecida em fogão elétrico utilizado exclusivamente para esse uso, pelo tempo de 30 minutos, após o início da passagem de vapor contínuo pela válvula de escape de vapor da panela.

\section{Resultados e Discussão}

Para a construção da incubadora de baixo custo desenvolvida neste trabalho, utilizou-se um kit comercialmente disponível para chocadeira de ovos acoplado a uma caixa de isopor, resultando em um equipamento caseiro com custo médio de $R \$ 166,00$, ou seja, cerca de 20 vezes menor em relação ao preço médio de incubadora bacteriológica padrão (Tabelas 1 e 2).

Schertenleib et al. (2019) avaliaram diferentes materiais (caixa de isopor, térmica de plástico rígido e de papelão associada a manta isolante térmica de emergência) para a construção de incubadoras de baixo custo para uso em detecção de microrganismos contaminantes de água para consumo humano. Ao invés de resistência elétrica espiral, utilizaram folhas de aquecimento flexível autoadesivas de $12 \mathrm{~V} / 20 \mathrm{~W}$, com o equipamento sendo produzido a um custo total aproximado de U\$300,00.

Oubre et al. (2016) indicaram incubadoras caseiras para o crescimento ótimo de bactérias para o uso na iniciativa "Treine como um Astronauta" da NASA (EUA), utilizando caixa térmica de plástico rígido ou aquário de vidro 
com lâmpada incandescente instalada em seu interior, mas sem controle preciso de temperatura.

Da mesma forma, as análises dos custos de preparação dos meios caseiros ágar nutriente caseiro 1 (ANC1) e ágar nutriente caseiro 2 (ANC2), indicaram que estes poderiam ser produzidos com custo médio duas vezes menor em relação ao meio de cultura ágar PCA comercial (Tabelas 1, 3 e 4).

Tabela 1: Custos de materiais convencionais utilizados em Laboratório de aulas práticas de Microbiologia, similares aos que foram formulados e construídos neste trabalho

\begin{tabular}{|c|c|}
\hline Material & Custo \\
\hline $\begin{array}{l}\text { Estufa bacteriológica, capacidade 40L } \\
\text { (Sterilifer, modelo SX1.0DTMC) }\end{array}$ & $\mathrm{R} \$ 3.745,00(\mathrm{em} \mathrm{27/02/2019)}$ \\
\hline $\begin{array}{l}\text { Estufa bacteriológica, capacidade 30L (General } \\
\qquad \text { Med) }\end{array}$ & $\mathrm{R} \$ 3.472,00$ (em 27/02/2019) \\
\hline $\begin{array}{l}\text { Estufa bacteriológica, capacidade 42L (Solab, } \\
\text { modelo SL-101/42) }\end{array}$ & $\mathrm{R} \$ 2.736,00(\mathrm{em} \mathrm{27/02/2019)}$ \\
\hline $\begin{array}{l}\text { Ágar PCA para contagem de placas (Kasvi, } \\
\text { código K25-611001, frasco de } 500 \mathrm{~g} \text { ) }\end{array}$ & $\begin{array}{l}\mathrm{R} \$ 458,02(\mathrm{em} 07 / 03 / 019) ; 1 \text { frasco } \\
\text { prepara 21,28L); } \mathrm{R} \$ 21,52(1 \mathrm{~L})\end{array}$ \\
\hline $\begin{array}{l}\text { Ágar PCA para contagem de placas (Merck, } \\
\text { código } 1054630500, \text { frasco de } 500 \mathrm{~g} \text { ) }\end{array}$ & $\begin{array}{l}\mathrm{R} \$ 374,88(\mathrm{em} 07 / 03 / 2019) ; 1 \text { frasco } \\
\quad \text { prepara } 22,22 \mathrm{~L}) ; \mathrm{R} \$ 16,87(1 \mathrm{~L})\end{array}$ \\
\hline $\begin{array}{l}\text { Ágar PCA para contagem de placas (Acumedia, } \\
\text { código } 7157 \text {, frasco de } 500 \mathrm{~g} \text { ) }\end{array}$ & $\begin{array}{c}\mathrm{R} \$ 356,49(\mathrm{em} 07 / 03 / 2019) ; 1 \text { frasco } \\
\quad \text { prepara } 21,27 \mathrm{~L}) ; \mathrm{R} \$ 16,76(1 \mathrm{~L})\end{array}$ \\
\hline
\end{tabular}

Fonte: Design de Lucy Ono

Tabela 2: Custos dos principais componentes para confecção da incubadora de isopor

\begin{tabular}{cc} 
Componente da incubadora & Custo \\
Kit Chocadeira (Digitle, modelo D1) & $\mathrm{R} \$ 120,00(\mathrm{em} \mathrm{10/04/2018)}$ \\
Caixa de isopor de 45L (Isoterm) & $\mathrm{R} \$ 46,00(\mathrm{em} \mathrm{25/04/2018)}$ \\
\hline Total & $\mathrm{R} \$ 166,00$ \\
\hline \multicolumn{2}{c}{ Fonte: Design de Lucy Ono }
\end{tabular}

Tabela 3: Custos dos componentes secos para confecção de 1L de formulação de ANC1

\begin{tabular}{|c|c|}
\hline Componentes & Custo \\
\hline $\begin{array}{c}\text { Fermento biológico fresco }(500 \mathrm{~g}) \\
\text { Ágar Kanten }(100 \mathrm{~g}) \\
\text { Áqua Mineral }(5 \mathrm{~L})\end{array}$ & 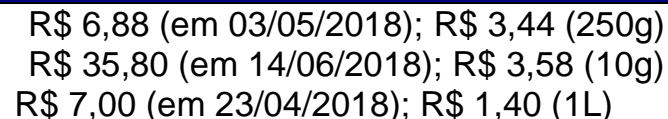 \\
\hline Total & $\mathrm{R} \$ 8,42 / 1 \mathrm{~L}$ \\
\hline
\end{tabular}

Tabela 4: Custos dos componentes secos para confecção de 1L de formulação de ANC2

\begin{tabular}{|c|c|}
\hline Componentes & Custo \\
\hline $\begin{array}{l}\text { Fermento biológico }(500 \mathrm{~g}) \\
\text { Isoflavona granel } 1 \mathrm{~kg})\end{array}$ & 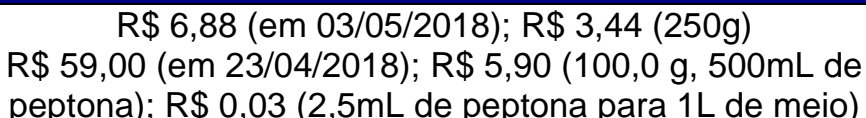 \\
\hline Abacaxi Hawaí (1 unidade) & $\begin{array}{l}\mathrm{R} \$ 5,98 \text { (em } 03 / 05 / 2018 \text {, para o preparo de } 500 \mathrm{~mL} \text { de } \\
\text { peptona); } \mathrm{R} \$ 0,03(2,5 \mathrm{~mL} \text { de peptona para } 1 \mathrm{~L} \text { de meio) }\end{array}$ \\
\hline Sal Rosa sem iodo $(100 \mathrm{~g})$ & 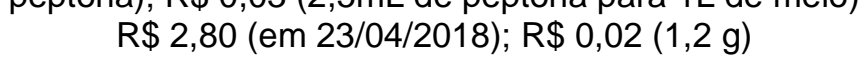 \\
\hline Ágar Kanten $(100 \mathrm{~g})$ & 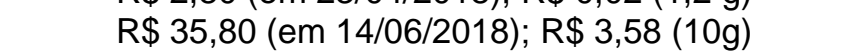 \\
\hline Aggua Mineral (5L) & $\mathrm{R} \$ 7,00(\mathrm{em} 23 / 04 / 2018) ; \mathrm{R} \$ 1,40(1 \mathrm{~L})$ \\
\hline TOTAL & $\mathrm{R} \$ 8,50 / 1 \mathrm{~L}$ \\
\hline
\end{tabular}


O uso de ágar Kanten para a solidificação dos meios produzidos neste trabalho substituiria o uso da gelatina incolor, cujos meios que a contém só podem ser incubados à temperatura ambiente e, em temperaturas ambientes mais altas, podem até ser liquefeitos, dificultando a obtenção de culturas de bactérias mesófilas (PALHETA; SAMPAIO, 2016). O ágar, constituído por uma mistura dos polissacarídeos agarose e agaropectina é considerado um agente gelificante ideal para meios de cultura bacterianos, por se fundir em água a temperaturas superiores a $100^{\circ} \mathrm{C}$ e solidificar-se próximo dos $40^{\circ} \mathrm{C}$, mantendose estável à temperatura de incubação de $\sim 37^{\circ} \mathrm{C}$ e não sendo facilmente degradado por enzimas bacterianas (MADIGAN et al., 2014).

O passo-a-passo da montagem da incubadora caseira é apresentado na Figura 1.

Nas formulações caseiras para meios de cultura bacterianos originalmente desenvolvidas por ZAREl et al. (2016) e GARVEY (2018), o reagente ágar-ágar foi indicado para a solidificação desses meios. No entanto, não há indicação da especificação necessária para o ágar utilizado.

O ágar Kanten a 10g/L solidificou levemente turvo-esbranquiçado e com consistência de corte adequada, enquanto o ágar-ágar a granel solidificou apenas na concentração mais alta testada $(40 \mathrm{~g} / \mathrm{L})$, adquirindo cor castanha opaca, com sedimento arenoso residual no fundo do tubo, além da consistência de corte ser macia e não adequada (Figura 2) para semeadura com Swab ou com alças de plástico ou de platina.

O ágar a granel, oriundo de Gracilaria spp. (alga vermelha da família Gracilaciaceae), sem tratamento alcalino prévio, produz géis mais fracos e mais opacos que o ágar Kanten oriundo de Gelidium (alga vermelha da família Gelidiaceae), devido ao maior teor de sulfato da porção agaropectina (FERREIRA, 2015).

As duas formulações avaliadas, ANC1 e ANC2, são diferenciadas pela adição de peptona de soja caseira e cloreto de sódio à última. Para a confecção dos meios, a autoclave necessária para o preparo do extrato de levedura e para a esterilização desses foi substituída pela panela de pressão. A etapa de centrifugação para obtenção do sobrenadante da suspensão lisada de leveduras foi substituída pela coleta cuidadosa do sobrenadante após resfriamento lento à temperatura ambiente (para que o recipiente de vidro não 
se quebrasse com o choque térmico), e resfriamento posterior em geladeira a $8^{\circ} \mathrm{C}$ (para dar maior estabilidade ao sedimento). Essa coleta foi realizada com pipeta de vidro e pipetador e passada por um coador de café contendo filtro de papel para obtenção de um extrato translúcido, o que no meio de cultura permitiria uma melhor visualização das colônias desenvolvidas.

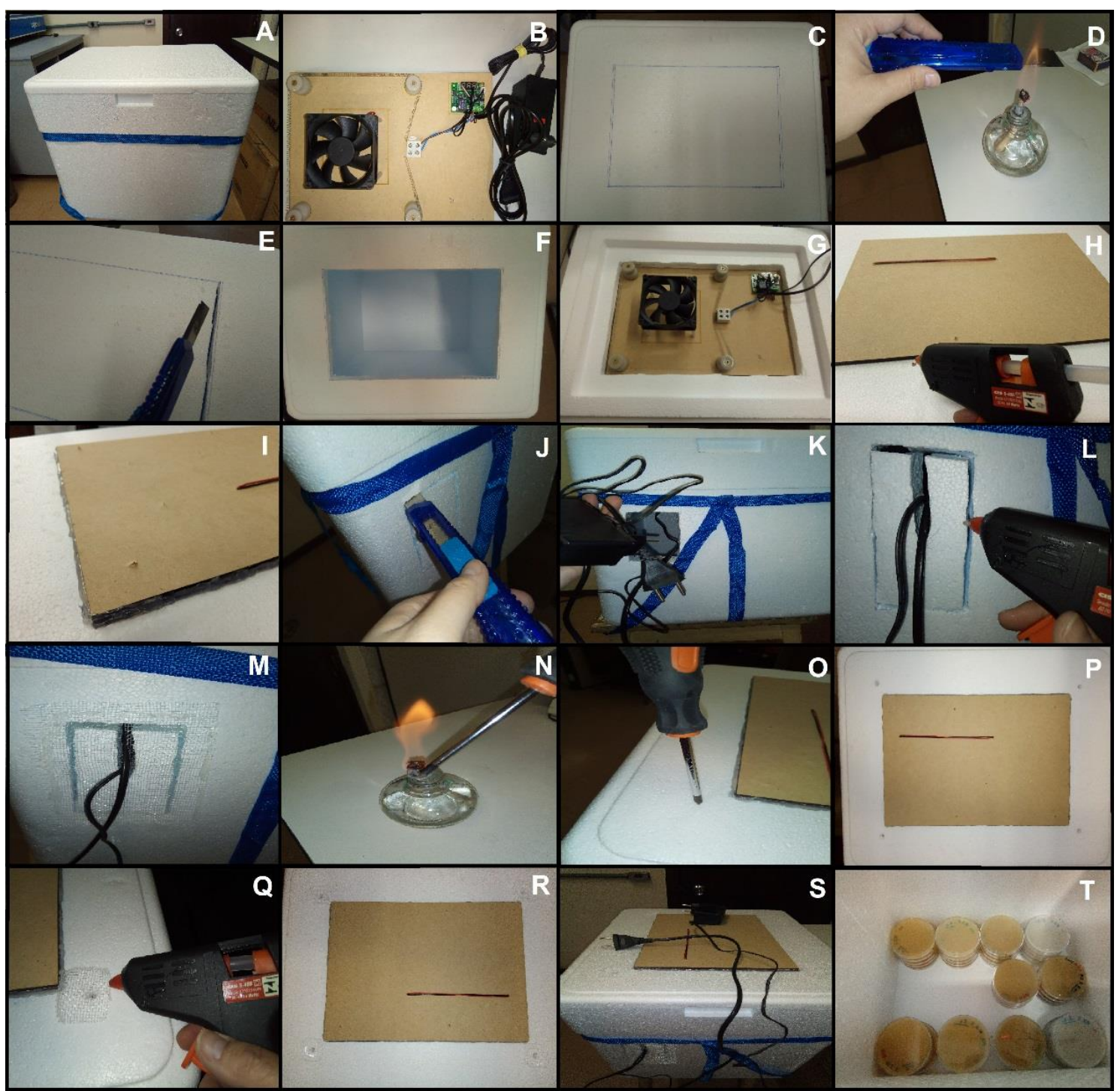

Figura 1 - Etapas de construção da incubadora de isopor. a) caixa de isopor; b) kit chocadeira; c) tampa marcada com as medidas da base do kit; d) aquecimento da lâmina de estilete; e) corte da tampa de isopor seguindo medida ligeiramente inferior à marcação realizada; f) tampa preparada para acoplar com a base do kit; g) conferência sobre o correto encaixe entre tampa e kit; h) posicionamento correto da tampa para a aplicação de cola quente; i) cola quente aplicada em toda a lateral da base de MDF; j) recorte lateral da caixa de isopor; k) retirada do cabo e da fonte após encaixe da tampa; I) colagem do pedaço lateral retirado na caixa de isopor após realizar corte central para o encaixe dos fios; $\mathrm{m}$ ) colagem de tela de nylon; n) aquecimento da ponta de chave Philips; o) furo feito na tampa para liberação de vapor; p) visão da tampa da incubadora com 4 furos; q) colagem de tela de nylon; r) furos protegidos por tela de nylon; s) incubadora montada com todos os componentes; t) placas com meios de cultura 


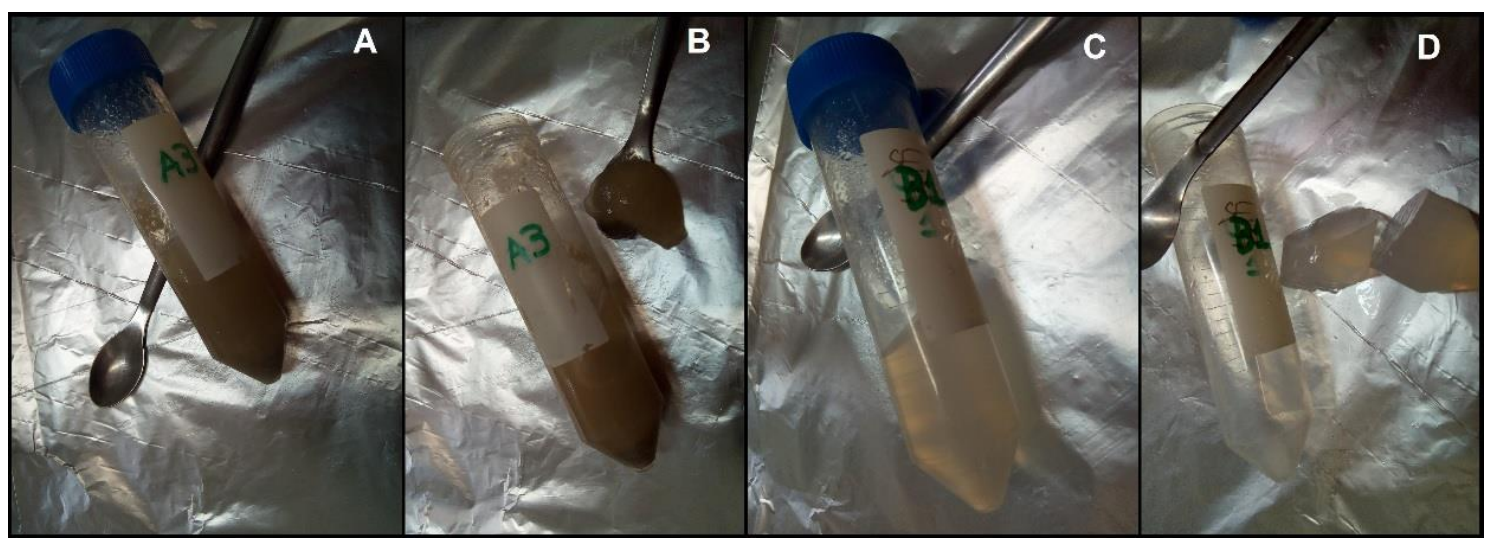

Figura 2 - Avaliação qualitativa da solidificação promovida por ágar a granel e paga Kanten. A,B) ágar a granel (Gracilaria sp., suspensão aquosa a 40g/L) e C,D) ágar Kanten (Gelidium sp., suspensão aquosa a $10 \mathrm{~g} / \mathrm{L})$, após autoclavação $\left(121^{\circ} \mathrm{C}, 20 \mathrm{~min}\right.$ ) e resfriamento, mostrando diferentes viscosidades ao serem cortados com espátula

Fonte: Design de Lucy Ono

As etapas descritas de preparação dos meios podem ser observadas na Figura 3. O meio ANC1 se mostrou menos turvo que o meio ANC2 devido à ausência da proteína hidrolisada de soja caseira na sua formulação.

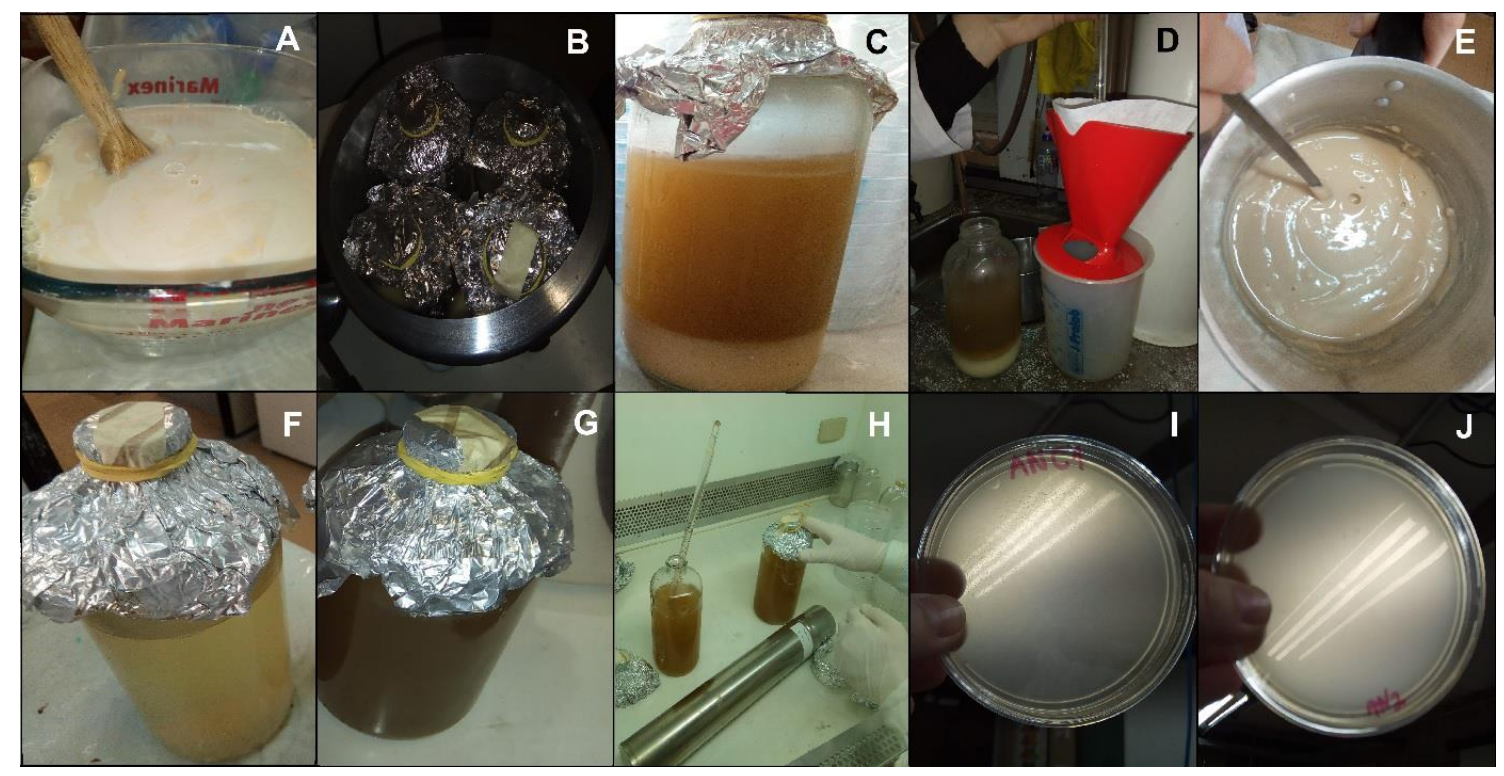

Figura 3 - Etapas envolvidas no preparo dos meios caseiros ANC1 e ANC2. A) Suspensão do fermento biológico caseiro em água mineral; B) Frascos com a suspensão de fermento biológico preparados para serem aquecidos em panela de pressão e fogareiro elétrico; C) Suspensão de fermento biológico após lise das leveduras por aquecimento em panela de pressão, resfriamento em temperatura ambiente e resfriamento em geladeira a $8^{\circ} \mathrm{C}$ por $72 \mathrm{~h} ; \mathrm{D}$ )

Filtração do sobrenadante utilizando papel de filtro de café e coador; E) Concentração da proteína hidrolisada de soja; F) ANC1 após esterilização em panela de pressão; G) ANC2 após esterilização em panela de pressão; H) Distribuição do meio de cultura ANC2 em placas em Petri de plástico ainda liquefeito; I) ANC1 solidificado em placa de Petri; J) ANC2 solidificado em placa de Petri.

Fonte: Design de Lucy Ono 
Utilizaram-se placas de Petri descartáveis de poliestireno para conter o meio de cultura bacteriano caseiro, mas estas podem ser substituídas por placas de Petri de vidro esterilizadas em panela de pressão. Não se recomenda o uso de copos de plástico por estes não estarem esterilizados e poderem contaminar de forma cruzada o meio de cultura.

Recomenda-se que, após a esterilização, o meio seja distribuído nas placas antes de atingir $40^{\circ} \mathrm{C}$, ou seja, antes de solidificar, utilizando técnicas assépticas. Logo após a distribuição, as tampas das placas devem ser fechadas. Se após a solidificação houver água condensada na tampa, esta deve ser aberta perto da chama de uma lamparina ou bico de Bunsen ou vela e a água condensada dispensada sobre outro recipiente movimentando a tampa, mas sem tocar a parte interna dela com as mãos ou sobre outras superfícies.

Quando incubadas em estufa de isopor, as placas de ANC1 e ANC2 apresentaram condensação de água, o que não aconteceu quando incubadas na estufa padrão, diferentemente do meio PCA. É possível que a condensação de água nas tampas das placas de meios caseiros tenha ocorrido em função de diferenças na composição e poder de gelificação do ágar Kanten comparado ao ágar bacteriológico usado no meio PCA (LEE et al. 2017).

Além disso, a falta de orifícios nas paredes laterais no fundo da caixa pode ter impedido o escoamento do vapor empurrado para baixo pelo cooler acoplado à placa de aquecimento. Recomenda-se que os meios sejam incubados por um período de 48 horas a $37^{\circ} \mathrm{C}$, previamente à semeadura, para que a água de condensação possa ser manualmente removida.

Para avaliar a eficácia da incubadora de isopor sobre o crescimento das bactérias padrões $E$. coli e $S$. aureus em comparação com o crescimento dessas em incubadora comercial, placas de ágar PCA foram semeadas e incubadas nessas duas incubadoras, suprimindo, portanto, a influência da composição do meio de cultura sobre o crescimento bacteriano.

Pôde-se verificar que utilizando o meio de cultura comercial, a incubadora de isopor permitiu crescimento de colônias bacterianas com morfologias e quantidades similares ao crescimento observado na incubadora comercial. Além disso, não houve diferença estatisticamente significativa na contagem de colônias de E. coliou S. aureus desenvolvidas (Figura 4). 
Como a incubadora caseira se mostrou adequada para o crescimento dessas espécies no ágar PCA, os meios caseiros também foram avaliados nela. Pode ser observado na Figura 5 que ANC1 e ANC2 apresentaram diferença estatisticamente significativa de crescimento da bactéria $S$. aureus em relação ao ágar PCA, com 13\% e 19\% menos colônias respectivamente. Em relação à bactéria $E$. coli, embora não tenha sido observada diferença estatisticamente significativa em relação ao ágar PCA, observou-se tendência de menor crescimento de colônias no ágar ANC2. Desse modo, o ágar ANC1 mostrou melhor desempenho e, como possui menos etapas de preparo, optouse por utilizá-lo para avaliar a semeadura de amostras ambientais.

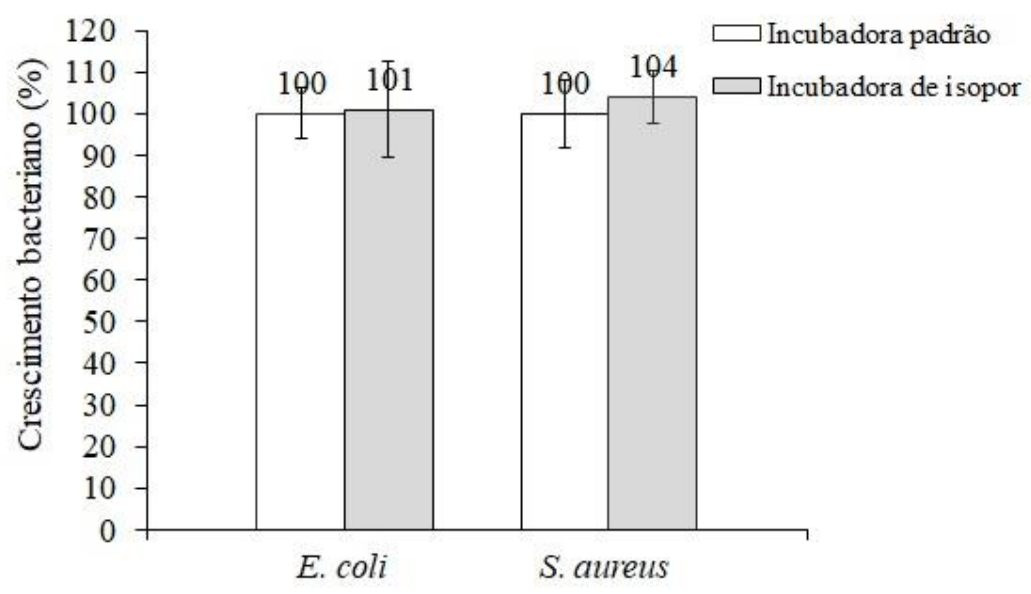

Figura 4 - Porcentagem de crescimento das bactérias padrões $E$. coli e $S$. aureus semeadas em ágar PCA comercial e incubadas em incubadora de isopor em comparação com o crescimento controle observado em incubadora padrão.

Fonte: Design de Lucy Ono

Esperava-se que ANC2 fosse permitir um melhor crescimento devido ao maior teor de nitrogênio com a adição de peptona, porém a formulação mais simples apresentou melhor resultado. Há ainda a possibilidade de não ter havido quebra da proteína de soja por ter sido utilizado suco de abacaxi para a proteólise pois não foram feitas análises da qualidade da peptona produzida. 


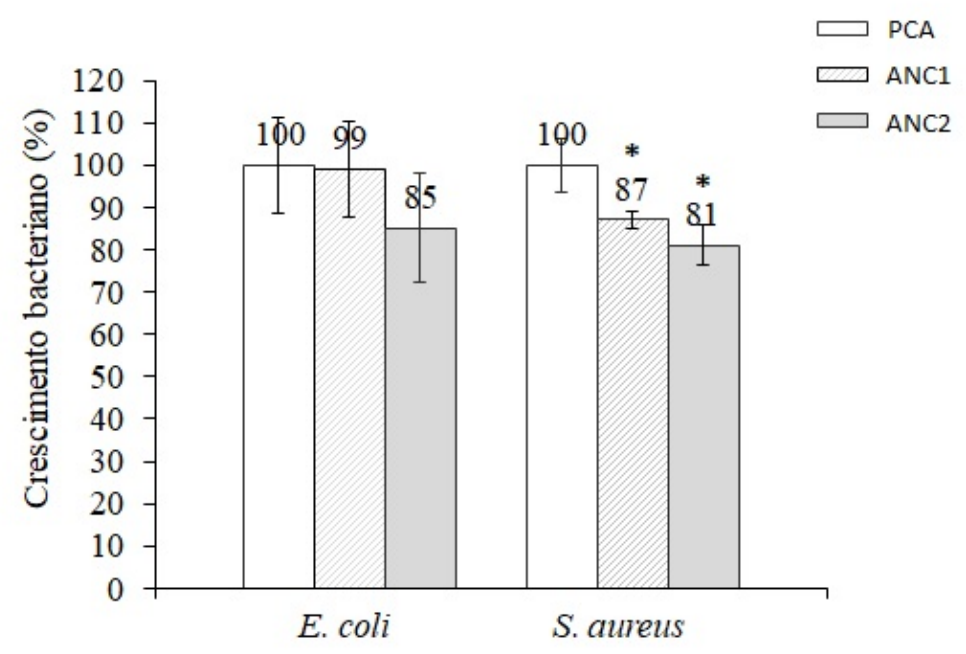

Figura 5 - Porcentagem de crescimento das bactérias padrões E. coli e S. aureus semeadas em ágar ANC1 e ANC2 e incubadas em incubadora de isopor em comparação com o crescimento controle observado em semeadura realizada em ágar PCA comercial. *Diferença estatisticamente significativa $(P<0,05)$.

Fonte: Design de Lucy Ono

Embora o desempenho de ANC1 em estufa caseira não tenha sido igual para as diferentes bactérias se comparado com o ágar PCA, foi possível observar um crescimento de pelo menos $80 \%$ do verificado em meio comercial. Salienta-se que essa diferença não foi observada na incubadora padrão, e é possível que a condensação de água observada no meio caseiro na estufa de isopor influencie no crescimento das colônias. Mas isso precisa ainda ser melhor investigado. O desenvolvimento de colônias de $E$. coli e $S$. aureus nas diferentes condições testadas (incubadoras e meios) pode ser observado na Figura 6. 


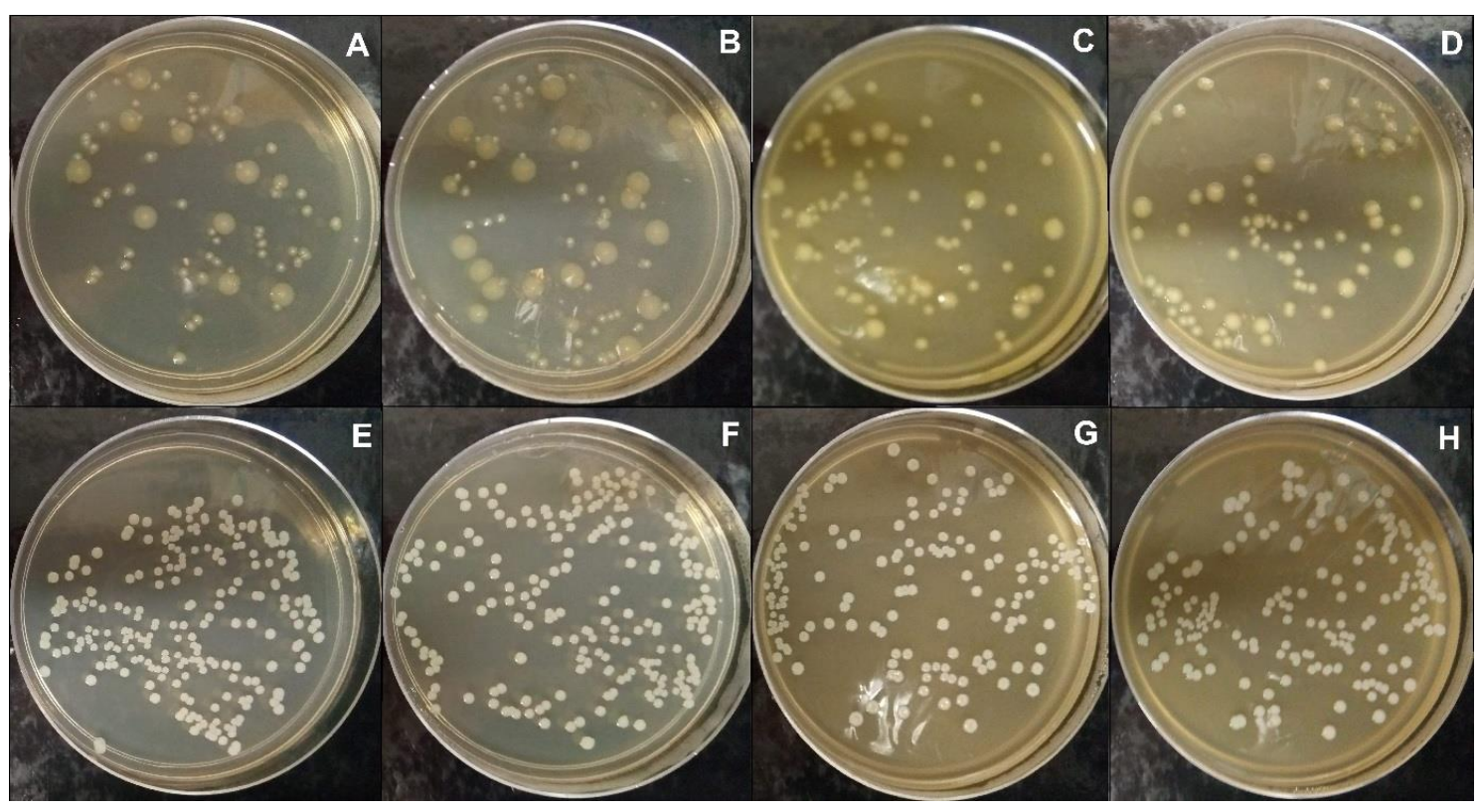

Figura 6 - Crescimento bacteriano em placas incubadas em diferentes incubadoras a $37^{\circ} \mathrm{C}$ por $48 \mathrm{~h}$. A) E. coli cultivada em PCA e incubadora convencional; B) E. coli cultivada em PCA e incubadora de isopor; C) E. coli cultivada em ANC1 e incubadora de isopor; D) E. coli cultivada em ANC2 e incubadora de isopor; E) $S$. aureus cultivada em PCA e incubadora convencional; F) S. aureus cultivada em PCA e incubadora de isopor; G) $S$. aureus cultivada em ANC1 e incubadora de isopor; H) $S$. aureus cultivada em ANC2 e incubadora de isopor

Fonte: Design de Lucy Ono

Zarei et al. (2016) já haviam avaliado o uso de extrato de levedura como única fonte de nutrientes para o crescimento de $E$. coli e $S$. aureus de forma qualitativa. O meio de cultura ANC1, diferentemente da composição original de ZAREI et al. (2016) que utilizava a massa obtida após a secagem em spraydryer do extrato de levedura (na proporção de 8 gramas de extrato em pó por litro de meio de cultura), utilizou extrato de levedura na forma líquida, dispensando a centrifugação e secagem por spray-dryer.

As colônias desenvolvidas no meio caseiro ANC1, inoculado com amostras do ambiente e incubado em estufa de isopor, podem ser observadas na Figura 7. Foram semeados Swab de superfície de válvula de descarga de banheiro, impressão digital e de tela de smartphone. Foram observadas em algumas das colônias analisadas: cocos Gram +, bacilos Gram + e bacilos Gram - (Figura 8), indicando que o meio utilizado permitiu o crescimento de bactérias com morfologias e afinidades ao Gram comumente encontradas no ambiente e em pele (SILVA et al., 2014). 


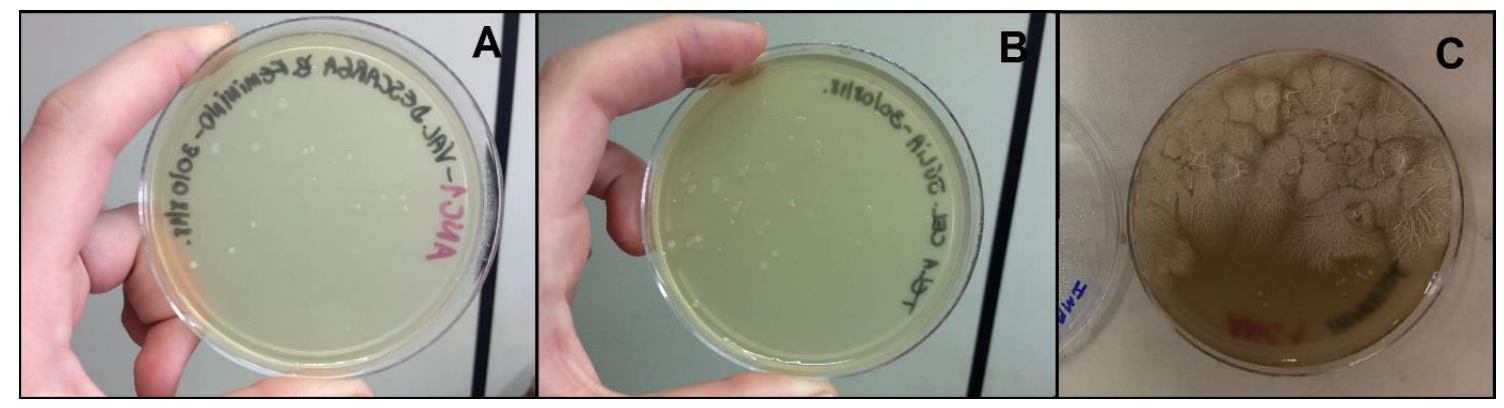

Figura 7 - Isolamento de colônias bacterianas no meio de cultura caseiro ANC1 a partir de amostras diversas após 48 horas de incubação a $37^{\circ} \mathrm{C} \mathrm{em}$ incubadora de isopor. A) semeadura de Swab de válvula de descarga de banheiro; B) semeadura de Swab de tela de smartphone; C) semeadura de Swab de impressão digital

\section{Fonte: Design de Lucy Ono}

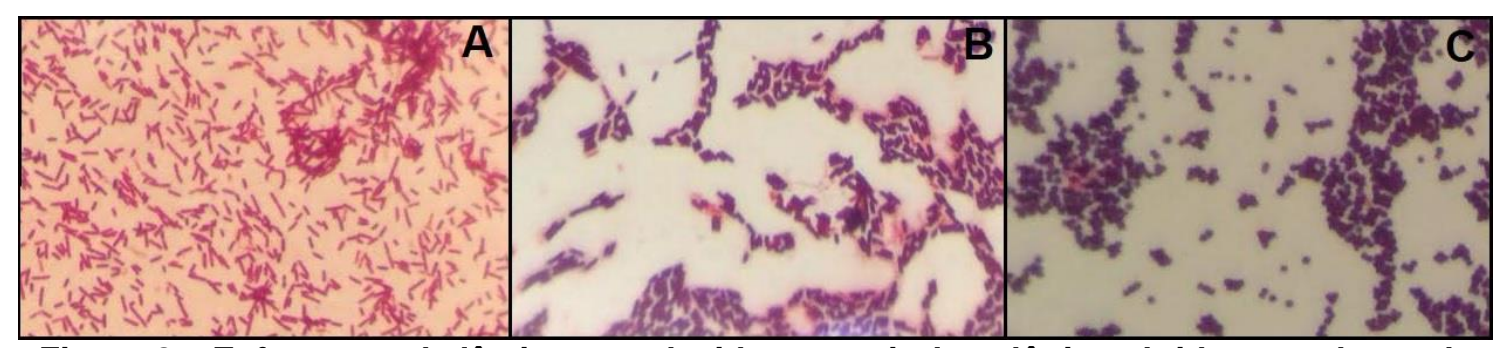

Figura 8 - Esfregaços de lâminas produzidas a partir de colônias obtidas em placas de ANC1 incubadas em incubadora de isopor, coradas pela técnica de Gram e observadas ao microscópio óptico de campo claro com objetiva de 100x (imersão) e ocular de 10x. A) bacilos Gram negativos; B) bacilos Gram positivos; C) estafilococos Gram positivos

Fonte: Design de Lucy Ono

\section{Conclusão}

A incubadora de isopor e o meio caseiro ANC1 apresentaram bom potencial para uso como materiais alternativos para a realização de aulas práticas de Microbiologia, e poderiam propiciar aos professores de Biologia do Ensino Médio uma estruturação inicial de laboratório de Microbiologia, onde práticas de baixo custo seriam realizadas.

\section{Referências}

BARBOSA, F.H.; BARBOSA, L.P.J.L. Alternativas metodológicas em Microbiologia: viabilizando atividades práticas. Revista de Biologia e Ciências da Terra, v. 10 (2), p. 134-143, 2010.

BOLTON, S. Pharmaceutical Statistics - Practical and Clinical Applications. New York: Marcel Dekker, 1990, 645p. 
BRASIL. Ministério da Educação. Diretriz Curriculares Nacionais da Educação Básica. Brasília: MEC, 2013. Disponível em: http://portal.mec.gov.br/docman/julho2013-pdf/13677-diretrizes-educacao-basica-2013-pdf/file. Acesso em: 05 set. 2020.

BRASIL. Ministério da Educação. Base Nacional Comum Curricular. Brasília. MEC, 2020. Disponível em

http://basenacionalcomum.mec.gov.br/images/BNCC El EF 110518 versaofinal site. pdf. Acesso em: 05 set. 2020.

CÂNDIDO, M. S. C. et al. Microbiologia no ensino médio: analisando a realidade e sugerindo alternativas de ensino numa escola estadual paraibana. Ensino, Saúde e Ambiente, v. 8 (1), p. 57-73, 2015.

CASSANTI, A. C. et al. Microbiologia democrática: estratégias de ensinoaprendizagem e formação de professores. Enciclopédia Biosfera, Goiânia, Instituto Construir e Conhecer, v. 4, n. 5, p. 1-27 (on-line), 2008.

CHICOSKI, L.M.; MARCONI, C.; CARON, L.F.; ONO, L.; BEIRÃO, B.C.B. Roteiro de Aulas Práticas para Microbiologia Veterinária. Recurso Educacional Aberto depositado no Repositório Digital Institucional da UFPR. Disponível em https://acervodigital.ufpr.br/handle/1884/60609. Acesso em: 17 nov. 2020.

DELGADO, A. DIYbio: Making things and making futures. Futures, v. 48, p. 65-73, 2013.

FERREIRA, D. M. O. Extração de ágar de algas vermelhas do gênero Gracilaria. 91 f. Dissertação (Mestrado em Processos Químicos e Biológicos). Instituto Superior de Engenharia de Coimbra, Coimbra, 2015.

GARVEY, C. Homebrew Media for the Microbiology Hobbyist. Disponível em: https://www.indiebiotech.com/uploads/guides/Homebrew-Bacterial-Media.pdf. Acesso em: 17 fev. 2018.

GITTI, V. L. et al. Aprendendo com os microrganismos: uma proposta prática. Ensino, Saúde e Ambiente, v. 7, n. 1, p. 1-10, 2014. 
KAMIYAMA, Y. Experiências sobre a utilidade da panela de pressão como autoclave. Revista da Escola de Enfermagem da USP, v. 4 (1-2), p. 55-79, 1970.

KRASILCHIK, M. Prática de Ensino de Biologia, $4^{a}$ ed., São Paulo: Editora da Universidade de São Paulo, 2008, 197p.

LANDRAIN, T. et al. Do-it-yourself biology: challenges and promises for an open science and technology movement. Syst Synth Biol, v. 7, p. 115-126, 2013.

LEE et al. Factors affecting yield and gelling properties of agar. J Appl Phycol, v. 29, p. 1527-1540, 2017.

MADIGAN, M. et al. Brock Biology of Microorganisms. 14 ${ }^{\text {th }}$ ed. Pearson, 2014, 985p.

OVIGLI, D.F.B.; SILVA, E.B. Microrganismos? Sim, na saúde e na doença! Aproximando universidade e escola pública. In: Anais do Simpósio Nacional de Ensino de Ciência e Tecnologia, UTFPR, v. 1, 2007, p. 396-416, 2009.

OUBRE, C. et al. Mission X: Train Like an Astronaut What's in your Petri BUGS IN SPACE PART 2. NASA Johnson Space Center Human Research Program Education Outreach, 2016. Disponível em:

https://www.nasa.gov/sites/default/files/atoms/files/microbeactivitypart2-petri.pdf. Acesso em: 02 set. 2020.

PALHETA, R.A.; SAMPAIO, A.P.L. Atividades práticas sobre microrganismos no aprendizado do ensino médio. Revista de Educação, Ciência e Tecnologia do IFAM, v. 10, n. 1, p. 72-87, 2016.

SANGIONE, L.A. et al. Princípios de biossegurança aplicados aos laboratórios de ensino universitário de Microbiologia e Parasitologia. Ciência Rural, v. 43, n. 1, p. 9199, 2013.

SCHELEY, T.R.; SILVA, C.R.P.; CAMPOS, L.M.L. A motivação para aprender Biologia: o que revelam os alunos do Ensino Médio. Revista da SBEnBio, v. 7, p. 4965-4974, 2014. 
SCHERTENLEIB, A. et al. Construction of a Low-cost Mobile Incubator for Field and Laboratory Use. Journal of Visualized Experiments, v. 145, e58443, 2019.

SILVA et al. Isolamento e identificação de microrganismos presentes em superfícies de teclados e mouses de uma universidade de Três Lagoas, MS. Colloq Vitae, v. 6 (3), p. 83-90, 2014.

ZAREI, O. et al. A Simple and Rapid Protocol for Producing Yeast Extract from Saccharomyces cerevisiae Suitable for Preparing Bacterial Culture Media. Iranian Journal of Pharmaceutical Research, v. 15 (4), p. 907-913, 2016. Disponível em: https://www.ncbi.nlm.nih.gov/pmc/articles/PMC5316271/. Acesso em: 02 set. 2020.

\section{Agradecimentos}

À CAPES - Coordenação de Aperfeiçoamento de Pessoal de Nível Superior pelo apoio financeiro ao PROFBIO - Programa de Mestrado Profissional em Ensino de Biologia em Rede Nacional. 